Makale türü / Article type: Araştırma / Research

\title{
Hastane İşletmelerinde İç Denetim ve Hile Denetimi İlişskisi Üzerine Bir Değerlendirme \\ ****
}

\section{An Evaluation on the Relationship between Internal Audit and Fraud Audit in Hospital Business}

\author{
Doç. Dr. Serkan Akçay \\ Artvin Çoruh Üniversitesi, Hopa İ̈BF, serkan.akcay@artvin.edu.tr \\ (ORCID: 0000-0003-0646-4239) \\ Merve Uysal \\ Artvin Çoruh Üniversitesi, Hopa İIBF, merve280889@ hotmail.com \\ (ORCID: 0000-0002-7315-5682)
}

\begin{abstract}
Özet
$\mathrm{Bu}$ çalışmada, hastane işletmelerinde iç denetimin hile denetimi ile ilişkisi incelenmiştir. Hastane işletmelerinin fonksiyonları ve özelliklerinden bahsedilmiştir. Çalışmanın amacı; hile ve yolsuzlukların hastane işletmelerinde nasıl yapıldığı ve hile ve yolsuzlukta mücadelede iç denetim ve iç kontrolün rolünün ne olduğudur. Çalışma, derleme yöntemi ile yapılmıştır. Sağlık alanındaki gelişmeler ve bu gelişmelerin büyük bir çoğunluğunun teknolojik kökenli olması, hastanelerin sadece sağlık birimi olarak değil, önemli bir ekonomik birim haline gelerek, hastane işletmeciliğinin önemi daha da artmıştır. Hastanelerde personel ücret ödemeleri, sigortalar ve ihaleler gibi alanlarda hile yapma olasılıkları yüksektir. İşletmelerin iç kontrol yapısının güçlü olması ve buna bağlı olarak etkin bir iç denetim, hastanelerde hile ve yolsuzluklarla mücadelede etkili olacaktır. Çalışma, hastanelerde yapılması muhtemel hileler ile iç denetimin hileler üzerinde etkisine ve yararlarına değinilmiştir.
\end{abstract}

Anahtar Kelimeler: Hastane, Hile, İç Denetim, Kontrol

Jel Sinıflandırması: M41, M42

\begin{abstract}
In this study, the relationship between internal auditing and fraud auditing in investigated. The functions and characteristics of hospital enterprises are mentioned. Purpose of the study; how fraud and corruption are performed in hospital enterprises; and what is the role of internal audit and internal control in the fight against fraud and
\end{abstract}


corruption. The study was conducted by compilation method. The developments in the field of health and the fact that the vast majority of these developments are of technological origin, hospitals have become more important not only as a health unit but also as an important economic unit and the importance of hospital management has increased. In hospitals are likely to cheat in areas such as personnel wages, insurance and tenders. The strong internal control structure of the enterprises and an effective internal audit will be effective in the fight against fraud and corruption in hospitals. The aim of this study is to investigate the possible frauds in hospitals and the effects and benefits of internal auditing on frauds.

Keywords: Hospital, Fraud, Internal Audit, Control

JEL Classification: M41, M42

\section{GİRIŞ}

Sağl1k, herkesi ilgilendiren önemli bir kavramdır. Gelişmelerle birlikte, hastalıkların tedavisinde yapılan pahalı araştırmalar ve hastanelerin önemli birer ekonomik birimler olduğu düşüncesi ile hastane işletmesi kavramının önemi gün geçtikçe artmaktadır.

Hastane işletmesi; "Kişilerin sağlık ihtiyaçlarını karşılamak amacıyla, sağl1k hizmetleri üretim faktörlerini bir araya getiren, sağl1k hizmeti üreten ve sunan, ekonomik değere sahip, hizmet üretim işletmeleridir" şeklinde tanımlanabilmektedir (Semerci, 2010, s. 26). Hastane işletmeleri amaçlarını gerçekleştirmek için; tıbbi, idari, mali, teknik fonksiyonlar gibi birtakım fonksiyonlara sahiptir. Hastane işletmeleri yapıları gereği diğer işletmelerden farklılık gösterebilmektedir. Karmaşık bir yapıya sahiptirler ve en önemlisi hizmet üretmektedirler.

Yaşamımızın her alanında en küçüğünden en büyüğüne kadar karşılaştı̆̆ımız birçok hata ve hile mevcuttur. Bu durum diğer işletmelerde meydana geldiği gibi hastane işletmelerinde de görülebilmektedir. Hata ve hileler sonucunda ciddi zararlar ortaya çıkmaktadır. Bu zararların önlenmesi ve tespit edilmesi için hastane işletmelerinin etkin bir iç kontrol yapısına sahip olması gereklidir. Etkin bir iç kontrol yapısı, hile yapma olasılığ 1 bulunan kişileri caydırır. Çünkü, iç kontrol sisteminde açık bulunmaması hile fırsatını ortadan kaldırır.

İç denetim ise; "İşletmenin gerçekleştirdiği faaliyetlerin, üst yönetim 
tarafından belirlenmiş plan, program, strateji ve misyonlara uygunluğunun ölçülmesi ve işletmenin iç kontrol sisteminin etkin ve verimli olup olmadığının sistematik bir şekilde denetlenme sürecidir" şeklinde tanımlanabilir (Kayıkçıŏlu, 2017, s.12). İç denetim hastane işletmelerinde var olan iç kontrol sisteminin yeterli olup olmadığını denetleyerek, olası riskleri ortaya çıkarması bakımından iç kontrol ile yakın bir ilişkidedir.

Sigorta kapsamında, nakit hesaplarında, reçetelerde, stoklar hesabında, alacaklar, hasta kayıtları ve bunun gibi çeşitli alanlarda hastane işletmelerinde hileler görülmektedir. Güçlü bir iç kontrol yapısı ve etkin bir iç denetim ile zararları önlemek mümkün olabilecektir.

\section{LITERATÜR İNCELEMESI}

Çalış ve Diğerleri (2014), çalışmada hile türlerinin sürekli değişiminden dolayı ve gelişen işletme data tabanları sebebiyle klasik denetim tekniklerinin hileleri engellemede ve ortaya koymada yetersiz kalmasından bahsedilmektedir. Bundan dolayı, bilişim sistemlerinin kullanılmasını kapsayan proaktif yaklaşımların hilelerin önlenmesinde ve ortaya konulmasındaki önemine değinilmektedir.

Güneş (2014), çalışmada muhasebe sistemi iyi kurgulansa bile çalışanların yetki ve sorumluluğu denk olmayınca ve doğru bir yetkilendirme yapılmamışsa işletme hilelere daha açık olur. İşletme iç kontrol sistemi ise bu yetkilendirmenin çalışma derecesi kadar ancak iyi olabilir. Ayrıca, çalışmada hilelerin tamamen yok edilmesinin mümkün olmadığı ama en minimum seviyeye indirilmesi için sistemin dizayn edilmesi gerekliliğine değinilmektedir.

Koyutürk (2015), çalışmada müşteri ile satıcıların hile ile ilgili bilgilendirilmesi ve ilgili prosedürlerinin daha önceden detaylı olarak hazırlanmasıyla hilelerin engellenebileceği üzerinde durulmaktadır. İşletme kültürü, iç kontrol sistemi, işletme etik kuralları hilenin önlenebilmesinde önemli görülmektedir.

Erdoğan ve Mengi (2018), çalışmada hastane işletmelerinde hata ve hile ile ilgili risklerin ölçülmesinde, değerlendirilmesinde ve ortadan kaldırılmasında uygulanan kontrollere yönelik bir araştırma yapılmıştır. 
Ticarette globalleşmenin etlisiyle kontrolün zorlaştığının bu durumun da işletmeleri hilelere daha fazla açık hale getirdiği üzerinde durulmuştur.

Demir ve Diğerleri (2019), çalışmada, hileli finansal işlemlerin tespitinde hileli işlemlerin tekrar düzeyinin belirlenmesi ve iç denetim sisteminin hileli finansal raporlamayı engellemedeki rolünün önemi ortaya konmaya çalışılmıştır.

\section{HASTANE İŞLETMELERI}

Çağımızın getirdiği birçok yeni hastalık ve sağlık şartlarındaki olumsuzluklar, hastalıkların tedavisi ve olumsuz koşullarla mücadele için hastane işletmeciliğini ayrıca mühim hale getirmiştir (Uğurluoğlu vd.,2013:6).

Dünya Sağl1k Örgütü hastane işletmesini;" teşhis, tedavi, muayene ve rehabilitasyon hizmetleri olarak sağlık hizmetleri veren hastaların tedavi aldıkları yataklı kuruluşlardır" şeklinde tanımlamıştır (Can ve İbicioğlu, 2008, s.255).

Hastane işletmeleri ise kısaca; sağlık hizmetleri sunan işletmelerdir. Sağlık hizmetleri sunan bu işletmeler amaçlarını gerçekleştirebilmek amacıyla birtakım fonksiyonları yerine getirmek durumundadır. Literatürlerde bu fonksiyonlar değişik açılardan belirlenmekle beraber bu fonksiyonlarını şu şekilde sıralayabiliriz (Özbek,2014:73);

-Tıbbi fonksiyonlar; Hastane işletmelerinin en temel fonksiyonlarından biridir. Sağlık durumlarını kontrol ettirmek isteyen kimselere sunulan tıbbı tedavi, teşhis, gözlem, ameliyathane gibi hizmetleri içermektedir.

•İdari fonksiyonlar; İşletmeler için gerekli olan idari fonksiyonlar hastanelerde de geçerlidir. Planlama, örgütleme, yürütme, koordinasyon, denetim gibi faaliyetleri kapsamaktadır.

-Mali fonksiyonlar; Hastane personelinin temini, hasta ihtiyaçlarının belirlenerek karşılanması için yapılan giderler vb. kapsamaktadır.

-Teknik fonksiyonlar; Hastane işletmelerinde var olan her türlü araçgereç ve malzemelerin bakım ve onarımı, hastalar için gerekli olan hizmetleri 
kapsamaktadır (Özbek,2014:75).

-Eğitim fonksiyonu; Personelin, halkın, tıp öğrencilerinin eğitimlerini kapsamaktadır. Hastanelerde personel açısından yeni bilgi ve beceri kazanma, halk açısından ise; hastalıktan korunma, aile planlaması gibi temel konularda eğitim faaliyetlerini içermektedir.

-Araştırma ve geliştirme fonksiyonu; Hastalıklar sürekli olarak değişmekte, yeni hastalıklar ortaya çıkmaktadır. Bu tip durumlar için tedavi bulma, tıbbi yöntemlerin belirlenmesi için klinik içi ya da klinik dışı her türlü araştırma ve geliştirme faaliyetlerinden oluşmaktadır (Yiğittop,2008:14).

Hastane işletmeleri, sağlık ve ekonomik alanlarda faaliyet göstermektedir. Sağlık alanında, tıbbi konularda alınması gereken kararlar ve tedbirler söz konusu iken, ekonomik alanda ise, hastane işletmelerinin kendini ikame etme hususunda aldığı karar ve faaliyetler vardır (Kurt,2018:84).

Hastaneler bir hizmet işletmesi olmasına rağmen diğer işletmelere benzer ve farklı yönleri vardır. Hastanelerin çalışma sistemleri ve yapısı itibariyle çeşitli özellikleri vardır. Bunlar (Yiğittop,2008:9-13);

-Uzmanlaşma seviyesi bir hayli yüksektir,

-Karmaşık (matris) bir yapıya sahiptirler,

-Hastalar (Tüketiciler) uzman personel karşısında zayıf bir konumdadir,

-Bilgi asimetrisine sahiptirler,

-Profesyonellik durumu diğer işletmelere nazaran yüksek seviyededir,

-Tüketici otoritesine sahip değildir,

-Faaliyetler ertelenemez niteliğe sahiptir,

•Çıktı ve değerleme kriterlerinin belirlenmesi ve ölçümü zordur,

-Denetim eksikliği bulunmaktadır. 
Hastane işletmeleri üretim işletmesi değil, bir hizmet işletmesi olduğundan dolayı hizmet sunmaktadır. $\mathrm{Bu}$ sebeple hizmetlerin ücretlenmesinde maliyetlere değil, bakanlık tarifelerine uyulmaktadır. Hastane işletme yöneticileri ücretleri belirleyemediği için, maliyetleri kontrol altına almak amacıyla iyi bir muhasebe ve finans bilgisine sahip olmalıdır (Ayanoğlu vd., 2013, s.3). Temel faaliyet konusu hizmet üretimi ve hizmet üretim çıktısının sunumu olmasından ötürü hizmet üretimi maliyetleri maliyet muhasebesinin alanına girmektedir. Faaliyet türü hangi alanda olursa olsun her türlü işletmenin gelir ve giderlerini kontrol altına alarak muhasebe sistemlerine uygun kayda almalıdır (Kurt, 2018, s.92).

Ek olarak, hastane işletmelerinin üretim işletmelerinden bazı farklı özellikleri mevcuttur. Üretim işletmelerinde üretim ve tüketim arasında zaman farkı var iken, hastane işletmelerinde aynı anda gerçekleştirilir. Ürünler üretim işletmelerinde depolanabilir niteliktedir ancak hastane işletmelerinde ürün hizmet olduğundan dolayı depolanamaz. Hastane işletmeleri tüketiciye özgü hizmet vermekte ve emek yoğun teknoloji ile çalışmaktadır (İsmmmoTesmer, 2013, s.16). Hasta sağlık hizmetlerine ihtiyaç duyan kişi olarak tanımlanabilmektedir. Hastane işletmelerindeki bahsettiğimiz tüketici kavramı bu konuda tartışmalar mevcut olsa da hastadır. Hastane işletmelerinin verdikleri sağlık hizmeti, üretimi ve tüketimi olan bir hizmet ürünüdür. Sağlık hizmetlerini talep ederek faydalananlar bir şekilde ödeme yapmaktadırlar. Bu nedenle kavramsal düzeyde hastalara tüketici demenin yanlış olmayacağı farz edilmektedir (Bostan, 2005, s.19).

\section{HILLE VE HATA KAVRAMI}

Hile kavramı kısaca bilinçli bir şekilde aldatma ve aldatılana herhangi bir zarar yükleme anlamına gelmektedir. Literatürde birçok tanımı mevcut olmakla birlikte hile kavramının belli başlı özellikleri bulunmaktadır. Bu özellikleri şu şekilde sıralayabiliriz (Hacıhasanoğlu ve Karaca, 2015, s.119);

-Hilede kasıt vardır, bilinçli olarak gerçekleştirme söz konusudur,

-Hileyi yapan kişi, kendine herhangi bir çıkar sağlama amacı güder,

•Hile eylemi sonucunda işletme zarar görmektedir,

•Hile eylemi gizli yapılmaktadır, 
-Genelde karşı taraf aldatılır.

Hata kavramı ise; kişinin kasıtlı olarak gerçekleştirmediği yanlışlıklar olarak tanımlanabilir. Muhasebe işlemlerinde hata ise yanlış hesaplamalar, muhasebe kayıtlarında yapılan hatalı kayıtlar, finansal durumdan fazla ya da düşük hatalı hesaplamalar gibi işlemlerden oluşur (DeFond ve Jiambalvo,1991, s.643). Ancak bilinmelidir ki hata ve hile arasındaki en büyük fark, hilenin kasıtlı olarak yapılması, hatada ise herhangi bir kastın söz konusu olmadığıdır.

Hatalar, temelde ihmal, bilgisizlik gibi durumlardan kaynaklanmaktadır. Hatalar (Erdoğan, 2018, s.91);

-Matematiksel hatalar,

-Kayıtta yapilan hatalar,

-Nakil hataları,

-Unutmadan kaynaklı hatalar,

•Çift kayıt hataları,

•Bilanço hataları, şeklinde sınıflandırılabilir.

Ancak hata ve hile ayrımını yapmak, sanıldığı gibi kolay değildir. Bu nedenle bazı ilkelere göre hareket edilmeli ve denetlemeler sırasında bu ilkeler göz önünde bulundurulmalıdır.

-İşletmelerin hesap işlemlerinde kişiler muhasebenin temel kurallarını bilmektedir, bu nedenle olağandışı durumlar haricinde önemli derecedeki düzensizlikler hile olarak kabul edilmektedir,

-Finansal tablolar hazırlanırken, temel teşkil eden muhasebe belge ve kayıtların yanlış ya da eksik olarak kayda girilmesi,

-İşletme çalışanı, olayları veya bazı gerçekleri yanlış bir şekilde yorumlayarak, tahminlerin yanlış yapılmasına neden olması,

-Hesapların tasnif edilmesinde yanlışlıklar 
yapılabilmektedir(Dumanoğlu, 2005, s.350).

Ek olarak hile kavramı (Bircan, 2013, s.30);

•Varlıkların kötüye kullanılması,

-Hileli finansal raporlama,

-Yolsuzluk ve ahlaki olmayan davranışlar, şeklinde sinıflandırılmaktadır.

\section{HASTANE İSLETMELERİNDE HILE KAVRAMI}

Hastane işletmelerinde hile kavramı; tıbbi tedavi hizmetlerinde bilinçli olarak kandırma veyahut gerçeği olduğundan farklı bir şekilde yansıtarak haksız kazanç elde edilmesi anlamına gelmektedir. Sağlık alanında yapılan hileler ciddi anlamda zararlara yol açmaktadır (Mengi, 2013, s.40).

Hastane işletmelerinde yapılan bazı hileleri şu şekilde sıralamak mümkündür;

-Gerçekte sigortalı tarafından kullanılmamış bir hizmeti kullanılmış gibi göstermek,

•Sağlık sigortalarını kötüye kullanmak,

-Hileli tazminat talepleri yaratmak,

-Doktorların tek bir defada gerçekleştirebileceği işlemleri ayrı şekilde birden fazla yapılmış gibi göstermesi,

-Hayali tedaviler,

-Sigortalıya ait kimlik hırsızlığı dolandırıcılığı (Mengi,2013:42),

•Fonların kötüye kullanılması,

-Fonların tahrif edilmesi,

-Mal ve hizmet taleplerinin verilmemesi, 
-Malzemelerin fazla değerlenmesi,

-Standartların altında mal temin edilmesi,

-Tibbi kayitlarda sahtecilik,

•İzinsiz varlıkların elden çıkarılması,

-Hayali işcilerin maaşları vb. (Muslimat ve Hamid, 2012, s.42).

Bunlar gibi birçok hile sıralanabilir. Hileler hastane işletmelerinde olduğu kadar hayatımızın tüm alanında da bir şekilde yer almaktadır. Nasıl ki işletmelerde, kamu kurumlarında vb. kuruluşlarda çalışan hileleri, yönetici hileleri, müşteri hileleri gibi başlıklar altında incelenen birçok hile türü varsa hastane işletmelerinde de bu riskler mevcuttur.

Örneğin yukarıda sayılan hilelerden hileli tazminat talebi yaratmak, reelde hakedilmemiş tazminat talebi alabilmek amacıyla gerçekleştirilir. Verilen sağlık hizmetinin birden çok faturalandırılmasıyla, verilen hizmetten daha pahalı bir hizmet sunulmuş gibi yansıtarak, sigorta kapsamında olmayan işlemleri sigorta kapsamında göstererek, çok sayıda reçete elde etmek amacıyla çok sayıda doktor muayenesi almak şeklinde gerçekleştirilebilir (Mengi, 2013, s.41).

Önceleri reçetelerde hata ve hile yapma firsatları oldukça fazla idi. Dürüst olmayan doktor veya hastalar bu belgelerde hile gerçekleştirebilmekteydi. Ancak doktor ve eczacı arasındaki eczane hataları, hastalar tarafından gerçekleştirilen hileler gibi işlemler artık teknik sistemler yardımıyla azaltılabilir durumdadır (Rincavage, 2003, s.1).

Resmî gazetede yayımlanan acil sağlik hizmetleri yönetmeliğine göre; "Hastanelerde acil hizmet kapsamına giren hastaların hastane öncesi ve hastaneler arası nakilleri sırasında sunulan hizmetlerin bedeli, bağlı olduğu döner sermaye saymanlığı tarafindan hastaların bağlı oldukları sosyal güvenlik kuruluşlarına tahakkuk ettirilerek tahsil işlemi gerçekleştirilir. Ancak sosyal güvencesi olmayıp, ödeme gücü de bulunmayan hastalardan ücret talep edilemez" (Madde:37 (Değişik: RG-24/03/2004-25412). Ancak nakil durumlarında ödeme gücü olmayan hastalardan alınan ücretler de hileli 
işlem olma durumundadır.

Yolsuzluk ve ahlaki olmayan davranışlar da hile kapsamına girmektedir, rüşvet bunun en bilinen örneğidir. Huzurevleri, sağlık bakım kuruluşları gibi işletmelerde çalışan personeller de bu tip davranışları gerçekleştirebilir (Bircan, 2013, s.49).

ABD'de bulunan Ulusal Sigorta Suçları Bürosu tarafından hazırlanan verilere göre ülke ekonomisini sıkıntıya sokan suçlar arasında hileli işlemler de mevcuttur. Tüketicilerin hileli belgeler ve beyanlarla hastane işletmelerini aldatması, ilaç firmalarının sundukları reklamlarla tüketicileri aldatmasıyla verilen zararlar oldukça yüksektir (Erdem ve Kaya, 2015, s.262).

Kısacası işletmelerde aklımıza gelen hileler ve hile olasılıkları, aynı şekilde bir başka boyutta hastane işletmeleri kapsamında da değerlendirilebilir.

\section{HASTANE ISŞLETMELERINDE İÇ KONTROL VE İÇ DENETIM}

İç kontrol sisteminin birçok tanımı olmakla birlikte iç kontrol; "işletme faaliyetlerinin stratejileri ile uyumlu, verimli ve etkili bir şekilde yürütülmesi, sağlıklı bir varlık ve kaynak kullanımı, hata ve hile olasılıklarının tespiti, engellenmesi, muhasebe kayıtları ve finansal tabloların doğru ve güvenilir olması ve işletmelerin amaçlarına ulaşmasında yardımcı olması amacıyla yönetimin kullandığg yöntemlerdir" şeklinde tanımlanabilir (Doğan, 2018, s.12).

Hastaneler sağlığın korunması ve iyileştirilmesi konusunda büyük önem taşımaktadır. Toplumsal açıdan da önemli bir yere sahip olan hastane işletmelerinin kaynak kullanımı, etkinlik ve verimliliği hususunda daha da gelişmesi için işletme anlayışı ile yönetilmeleri gerekmektedir. Bunun için de sağlıklı işleyen bir iç kontrol sisteminin varlığı gerekmektedir (Doğan ve Burgazlığlu, 2015, s.20).

Hastane işletmelerinde iç kontrolün 3 temel amacı bulunmaktadır. Bunlar;

-Yapılan işlemlerin etkinlik ve verimliliğini arttırmak, 
•Finansal raporlamanın doğruluk ve güvenirliğini sağlamak,

•Yürürlükteki mevzuat ve kanunlara uygunluğu sağlamak.

Hastane işletmelerinde bu üç amaç yapılan tüm faaliyetleri içermektedir. Hastane işletmelerinde iç kontrol; yönetici kurulu, çalışanlar ve yöneticileri ilgilendiren, yukarıda sayılan amaçlara ulaşılması için makul bir güvence sağlamak amacıyla uygulanan bir süreçtir ve iş akışlarının içine yerleştirilmektedir (Erzurum, 2014, s.33).

Hastane işletmelerinde iç kontrol sistemi kurulurken birtakım unsurlar göz önünde bulundurulmalıdır. Bunlar (Can, 2014, s.118-119);

-Sigortalama; suistimal ve yolsuzlukları önlemek için çalışanlar sigorta kapsamına dahil olmalıdır.

-Eğitim; Hastane personeli, hastalar belli eğitimler görerek daha bilinçli hale getirilmelidir.

• Görevler Arasında Değiş̧im; başka görevlerde de görevi alan kişilerin bilgi sahibi olması amaçlanır.

-Bağımsız Kontroller; yapılan kontroller birbirinden bağımsız gerçekleşmelidir.

-Görevlerin Ayrılığı; hastanın hesabını onaylayan kişi ile hesabın şüpheli olduğuna karar veren kişi farklı kişiler olmalıdır. Bu unsurdaki temel amaç; hata ve hilelerin önlenmesi, hata ve hile var ise tespit edilmesidir (Kertiş, 2005:38).

-Uygun Yetki Verme; işletmede yetkiler departmanların iş alanlarına uygun olmalıdır. Örneğin, malzeme siparişi doğru departman tarafından verilmelidir.

-Dökümanların Yeterliliği; işletmede amaçları ve yöntemlerini kapsayan bir iç kontrol sistemine ve işlemlerinin belge ve kayıt altına alınarak, bunların belgelerine sahip olmalıdır (Kertiş,2005:40).

-Sistem Kontrolleri; iç kontrol sistem ve faaliyetlerinin, işletme 
yapısına katkı sağlayıp sağlamadığının analizi yapılarak, kalite kontrolünün yapılması ve kaynakların yeterliliğinin belirlenerek, değerlendirilmeye tabi tutulmasidir (Tufan,2012:29).

İç denetim kavramı iç kontrol ile ilişkilidir. Bu nedenle iç denetim kavramı; "İşletmenin gerçekleştirdiği faaliyetlerin, üst yönetim tarafından belirlenmiş plan, program, strateji ve misyonlara uygunluğunun ölçülmesi ve işletmenin iç kontrol sisteminin etkin ve verimli olup olmadığının sistematik bir şekilde denetlenme sürecidir" şeklinde tanımlanabilir (Kayıkçığlu, 2017:12).

Uluslararası Denetçiler Enstitüsü'nün 1999'da yaptığı tanıma göre ise iç denetim; "İşletmenin işlemlerine değer kazandırmak ve geliştirmek için yapılan bağımsız, objektif bir güvence ve danışmanlık faaliyetidir. Sistematiklik getirerek bir işletmenin hedeflerine ulaşmasında yardımcı olur, risk yönetimi, kontrol ve yönetişim süreçlerinin etkinliğini arttırmak için disiplinli bir yaklaşımla değerlendirmede bulunur" şeklinde tanımlanmıştır (Coram vd., 2006:5).

İç denetimin tanımlarından anlaşılacağı bazı fonksiyonları bulunmaktadır. Bunlardan en temel olanları güvence sağlama ve danışmanlık fonksiyonlarıdır. Güvence sağlama fonksiyonu iç denetçilerin yaptıkları değerlendirmelerde ve sundukları raporlarda bağımsız ve objektif olmalarıdır. Danışmanlık hizmetinde ise; usul ve yol gösterme, tavsiyelerde bulunma, işleri kolaylaştırma gibi faaliyetler gerçekleştirilmektedir (Yurtsever, 2015, s.93-94).

Hastane işletmelerinde iç denetim ise; hastane işletmelerinde uygulanan iç kontrol sisteminin etkin ve verimli olup olmadığının, riskler de göz önünde bulundurularak belli zaman aralıklarında gözlemlenmesi ve değerlendirilmesidir. İç denetim hastane işletmelerinin işlemlerinin gelişmesi ve değer kazanması hususunda, bağımsız, yansız bir şekilde uygulanması gerekli bir danışmanlık faaliyetidir. İç denetim aynı zamanda hastane işletmelerinin amaçlarına ulaşmasında yardımcı olmaktadır (Erzurum, 2014, s.37).

İç kontrol sürece odaklanarak, hile ve yolsuzluklar ortaya çıkmadan risklerin önceden belirlenip, tespit edilmesi amacına yönelik 
gerçekleşmektedir. Kayıplar ortaya çıkmadan bu durumun engellenmesi istenir. Hastanelerde uygulanan etkin bir iç kontrol sistemi, hile ve yolsuzlukların ortaya çıkmadan belirlenmesinde, hastanenin etkin ve verimli olarak çalışması, karlılığını etkileyecek herhangi olumsuzlukların tespit edilerek giderilebilmesi açılarından halk sağlığı açısından yapılan hata ve hileleri önlenmesi için büyük yarar sağlamaktadır (Doğan ve Burgazlığlu, 2015, s.31). İç kontrol bu yararı sayesinde oluşabilecek maddi kayıların önüne geçerek, muhasebe işlemleri ve finansal tabloların güvenirliğini sağlamaktadır.

Örneğin muhasebe işlemlerinde kasa hesabının önemi büyüktür. İyi bir kasa kontrolünün varlığı iç denetimin etkin olduğunun göstergesidir. Bildiğimiz üzere tüm işletmelerde kullanılan kasa hesabı elbette hastane işletmelerinde de kullanılan kilit bir hesaptır. Kasa hesabı diğer hesaplarla da ilişkilidir ve muhasebe kayıtlarının, finansal tabloların doğruluğunu etkiler. $\mathrm{Bu}$ hesaplarda hile ve hata olasılığı da yüksektir. İç kontrol kasa denetimi gerçekleştirerek, bu alandaki olası hilelerin önüne geçmeyi amaçlamaktadır (Yiğittop,2008:50). Kasa hesabında nakit tahsilatı kontrollerinde yolsuzluklar ile sık karşılanılmaktadır. Hastane işletmelerinin kasa hesabında iç kontrol sistemi sonucu karşılaşılan hileler genelde (Kertiş, 2005, s.44);

-Kayıtlanmadan ayakta tedavi hizmeti alan hasta hizmetlerinin nakit tahsilatına yönlendirilmesi,

-Kayıttan silinmişş̧üpheli alacakların tahsilinin cebe indirilmesi,

-Hastane işletmelerinde yapılan indirimleri, fazla söyleyerek, fazla nakdin çalınması,

-Kasa sayım sonucu çıkan fazlalıkları gizleyerek, elde etmek şeklinde olabilmektedir.

Muhasebenin temel hesaplarından olan stoklar da işletmenin önemli kalemlerindendir. Stoklar, hile ve suistimale açık hesaplardandır. Bu nedenle iç kontrol sistemi stoklar hesabında hileye karşı önlemler almalıdır. Stokların bozulması, israf edilmesini önlemek ve korumayı sağlamak, bu önlemlerden bazılarıdır(Usul ve Ateş, 2011, s.52). Stokların kayıtların muhasebe ilkelerine uygun olarak geçirilip geçirilmediği, finansal tablolara doğru biçimde 
yansıyıp yansımadığına bakılması gibi denetimler gerçekleştirilir (Ceran ve Bezirci, 2011, s.512). Hastane işletmelerinde ise stok kavramı diğer işletmelere nazaran biraz farklıdır. Çünkü, satışı gerçekleştirilen malzemeler hizmet üretiminde kullanılan mal ve malzemelerdir. Ancak hastane işletmelerinde de bu kalem bilançoda ağılığı olan bir hesaptır ve iç kontrol sistemi tarafından diğer işletmelerde olduğu gibi denetlenmelidir (Özbek, 2014, s.132).

Hastane işletmelerinin giderlerinin büyük bir kısmını oluşturan personel ücret ödemelerinde de hile ve yolsuzluklar yaşanabilmektedir. İşe alımlarla, işten çıkarmalarda, her türlü terfi işlemlerinde, faaliyetleri yürütmek üzere bir personel departmanı bulundurulması iç kontrol sistemi uygulaması için gereklidir (Kızıltuğ, 2015, s.53). Ödemelerin nasıl gerçekleştiği, ödeme tutarları vb. işlemler kontrol edilmelidir.

İç denetim kurumun tüm faaliyetleri, süreçleri ve çalışanları ile ilgilidir. İç denetim sadece finansal olan olaylarla değil finansal olmayan olaylarla da ilgilenmektedir. İç denetim, mali denetim, faaliyet denetimi, uygunluk denetimi, operasyonel denetim, risk yönetimi, kriz yönetimi ve hile ve yolsuzluk denetimi gibi denetimleri içine almaktadır. Son yıllarda meydana gelen hilelerde artış iç denetimi ve iç denetimin hile ve yolsuzluk denetimini de beraberinde getirmiştir.

Hata, hile ve yolsuzlukların, kazanç ve varlık kayıplarının önüne geçilmesinde, iç kontrol sistemi ve iç denetim faaliyetinin etkinliği oldukça önemlidir (Yurtsever, 2015, s.93).

Hile eylemi gerçekleştirecek kişi, işletmenin iç kontrol yapısında açik olup olmadığını kontrol eder, eğer açık varsa bu kişiye hile yapma fırsatını verir. $\mathrm{Bu}$ nedenle iç kontrol yapısı güçlendirilerek hile yapma olasılığının önüne geçilmelidir (Mengi, 2012, s.125).

Güçlü bir iç kontrol yapısı oluşabilecek hileleri önlemede oldukça yararlı olacaktır. Çünkü, hileli işlemlerde başarılı olmak için var olan kontrolleri aşmak gerekir. Hatta büyük tutarlı gerçekleştirilen hileler, konumları itibariyle kontrollerin güçlü ve zayıf yanlarını bildiklerinden dolayı genelde üst yöneticiler tarafından gerçekleştirilmektedir. Bu sebeplerden ötürü iç kontrol yapısı işlevleri (Erdem, 2014, s.54; Muslimat, 2012, s.55); 
•Hile eyleminin gerçekleşmesini zorlaştırıcı olmalıdır,

-Bazı durumlarda hile yapma riskini olanaksız hale getirmelidir,

•Eğer gerçekleşen bir hile varsa, hilenin ne olduğunun belirlenmesi ve sorumluların tespitinde aktif bir rol oynamalıdır.

Eğer işletmenin iç kontrol sisteminde eksiklikler mevcut ise ve eksiklikler belirlenip açık kapatılamıyorsa (Güreli, www.gureli.com.tr, 14.09.2019);

-İşletme varlıklarında azalma,

-Hatalı, yanlış kararlar alma ve uygulama,

$\bullet$ Hile ve yolsuzluk,

-Kazanç kaybı,

-Amaç ve hedeflere ulaşamama gibi durumlar gerçekleşir.

Hilelerin önüne geçmek için iç kontrol sistemi geliştirilmeli ve güçlendirilmelidir. Uluslararası Muhasebeciler Federasyonu'nun 2011 raporunda iç kontrolün geliştirilmesi için yapılması gereken işlevler sıralanmıştır. Bunlar (Atmaca, 2012, s.201-202);

-İç kontrol sistemi, hangi işletmede uygulanıyorsa o işletmenin amacına uygun olarak dizayn edilmeli, risk ve kurumsal yönetimle uyum içinde olmalıdır.

-İç kontrol işletmelerdeki görev ve sorumlulukları belirleyerek, birbirleri ile iletişim halinde olmalarını sağlamalıdır

- İç kontrol sistemi işletmede çalışan personellerin işletme amaçlarına ulaşmadaki performans düzeylerini ölçerek, değerlendirmelidir.

-İç kontrol sistemi, yetkin kurullar tarafından sorumlulukların yerine getirildiği bir ortam oluşturmalıdır.

•İç kontrol, sistemin hataları ve zayıflıklarını sürekli olarak 
değerlendirmek için işletme yönetimi ile iletişim halinde bulunmalıdır.

Yapılabilecek hilelerin tespiti, hileleri önleyici önerilerin bulunması, yöneticilere danışmanlık hizmeti gibi sebeplerden dolayı işletmeler iç denetime ihtiyaç duyarlar. Güçlü ve etkili bir kontrol için iç denetim şarttır. İşletmelerde iç denetim için yeterli kaynakların ayrılması gereklidir. İç denetim yetkin kişiler tarafından yapılmaktadır (Aktaş, 2015, s.44).

İç denetimin var olmasının sağladığı bazı faydalar aşağıdaki gibidir (Arslan, 2018, s.93-95);

-İşletme içi önceden tahmin edilemeyen, olumsuz sonuçlar doğurabilecek risklerin tespiti,

•Hata ve hilelerden kaynaklanabilecek zararların önüne geçilmesinde,

-Varlık ve kayıtların korunmasında yarar sağlar,

•Güvenilir bilgiler ve verimlilik artışı,

-Suistimallere ilişkin tedbirler sağlar,

-Yasa ve mevzuata uygunluğu sağlar,

-Finansal tablolar ve belgelerin iç denetim tarafından incelenmesi güvenilir bilgi sağlar.

Ayrıca, hasta kabulü ve kayıtların, nakit girişi olan hastane kafeteryaları, hasta vezneleri gibi yerlerin, laboratuvar departmanını vb. işlemlerde iç kontrol sisteminin yeterli olup olmadığını denetleyerek, açık var ise tespit eder ve riskleri değerlendirir (Can, 2014, s.127).

İşletmelerde güven esasının temelini iç kontrol sisteminin varlığı oluşturmaktadır. İşletmelerde etkin bir iç kontrol yapısı mevcut ise (Atmaca, 2012, s.199-200);

-İşletmenin iyi bir örgüt yapısına sahip olması,

-İşletmede uzmanlaşma, 
•Hata ve hilelerin önlenmesi,

-İşletmenin var olan zayıf noktalarının tespiti,

-Muhasebe sisteminin sağlamlığ 1 ,

-Personelin niteliği,

•İç denetim yapısı ile uyum olmalıdır.

Hastanelerde iç kontrol sisteminin etkin olması, hastalara düşük maliyet ile sağlık hizmetlerinin verilmesini ve israfın önüne geçilmesine yardımcı olur (Can, 2014, s.118). Ayrıca etkin bir iç kontrol sisteminde, yapılan denetimin alanı ve süresi azalarak denetim işi kolaylaşmakta, hile riski azalmaktadır. Ancak etkin olmayan, zayıf bir iç kontrol sistemi mevcut ise; denetimin alanı artar, süresi uzar, hile fırsatı artar ve denetim zorlaşır (Atmaca, 2012, s.200).

\section{SONUÇ}

İç denetim, iç kontrol sisteminin etkinliğini ölçen bir denetim türüdür. Kurumların iç kontrol sistemleri de hile ve hatalara açık sistemlerdir. İnsanın olduğu yerde hile ve hata olabilir, paranın olduğu yerde ise hile riski artmaya başlar. İnsan ve para bir araya geldiğinde ve bu durum kötü niyetle beslendiğinde, maddi menfaat elde etme isteği ile birlikte de hileler ortaya çıkar. İç denetim sistemi de tüm bu hileleri yakalamaya çalışan, süreç denetimi yapan bir birim olarak ortaya çıkmıştır. Hastaneler de günümüzde sadece tedavilerin yapıldığı sağlık kuruluşları değil, aynı zamanda satın alma ve hizmet satışı olarak çok yüksek paraların döndüğü büyük işletmelerdir. Ayrıca, çalışan sayısının çok fazla olmasından dolayı maaş ve döner sermaye harcamaları da yine çok fazlaca yapılan işletmelerdir. Nakit işlemlerin çokluğu ve yüksek meblağlarda olması hastanelerde hile yapılma olasılığını güçlendirir. İç denetim, risk odaklı süreç denetimi yaptığı için ve iç kontrolün denetimini sürekli denetlediği için hileler üzerindeki caydırıcılığı geleneksel denetim yöntemine göre ve haliyle de sonuç odaklı olarak yapılan dış denetime göre daha yüksektir. İç kontrol sisteminin sürekli iyileştirilmesi ve güçlendirilmesi hastane işletmeleri için çok önemlidir. Riski yüksek alanlardan iç denetime başlanmalı ve özellikle ihaleler başından sonuna kadar çok iyi takip edilmelidir. Böylelikle, hastalara daha düşük maliyetle hizmet 
verebilme durumu söz konusu olabilir ve devletten talep edilen ve gerçek harcamalardan daha yüksek olan hayali ödeneklerin önüne geçilmiş olur. Ayrıca, hastane işletmelerinde iç kontrol prosedürlerinin güncellenmesi, ihbarlara önem verilmesi ve üzerine gidilmesi, personel seçiminde dürüstlük testlerinin yapılması, hile ve iç denetimle ilgili eğitim faaliyetlerinin düzenli olarak personele belirli aralıklarla verilmesi ve etik ilkelerin benimsetilmesi gibi faaliyetlere önem veren bir organizasyon yapısı oluşturulmalıdır.

\section{KAYNAKLAR}

Aktaş, E. (2015). İç Denetim ve Risk Yönetimi İlişkisi. Yüksek Lisans Tezi., İstanbul: İstanbul Ticaret Üniversitesi, Sosyal Bilimler Enstitüsü.

Arslan, Ö. (2018). Muhasebe Hilelerinin Tespitinde İç Denetim Sisteminin Önemi ve Denetim Standartları Açısından Bağımsız Denetçinin Hileye Karşı Sorumluluğu: Bağımsız Denetim Şirketlerinde Bir Araştırma. Doktora Tezi, Sivas: Cumhuriyet Üniversitesi, Sosyal Bilimler Enstitüsü.

Atmaca, M. (2012). Muhasebe Skandallarinin Önlenmesinde İç Kontrol Sisteminin Etkinleştirilmesi: Afyon Kocatepe Üniversitesi İktisadi ve İdari Bilimler Fakültesi Dergisi, 14(1), 191-205.

Ayanoğlu, Y., Abuhanoğlu, H., \& Teke, A. (2013). Sağlık Hizmetleri Yönetimi Eğitiminde Muhasebe ve Finansman Derslerinin Önemi: Gazi Üniversitesi İktisadi ve İdari Bilimler Fakültesi Dergisi, 15(1), 1-19.

Bircan, N. G. (2013). Kar Amaçsız İşletmelerde Hile Denetimi. Yüksek Lisans Tezi, İstanbul: Marmara Üniversitesi, Sosyal Bilimler Enstitüsü.

Bostan, S. (2005). Hastane İşletmelerinde Müşteri (Hasta) Beklentileri Araştırması. Yüksek Lisans Tezi, Trabzon: Karadeniz Teknik Üniversitesi, Sosyal Bilimler Enstitüsü.

Can, A. \& İbicioğlu, H. (2008). Yönetim ve Yöneticilik Yönünden Üniversite Hastanelerinin Değerlendirilmesi: Süleyman Demirel Üniversitesi İktisadi ve İdari Bilimler Fakültesi Dergisi, 13(3), 253-275.

Can, E. N. (2014). Hastane İşletmeciliğinde İç Kontrol Sisteminin Etkinliği. Doktora Tezi, İstanbul: Marmara Üniversitesi, Sosyal Bilimler Enstitüsü.

Ceran, Y., \& Bezirci, M. (2011). Stok Hesaplarının Denetiminde İç Kontrol Sistemi ve İç Denetimin Önemi: Sosyal Ekonomik Araştırmalar Dergisi, 11(22), 507 536.

Coram, P., Ferguson, C., \& Moroney, R. (2006). The Value of Internal Audit in Fraud Detection: Journal of Accounting and Finance, 48(4), 543-549. 
Çalış, Y.E., Keleş, M., \& Engin, A. (2014). Hilenin Ortaya Çıkartılmasında Bilgi Teknolojilerinin Önemi ve Bir Uygulama: Muhasebe ve Finansman Dergisi, 63, 93-108.

DeFond, M. L., \& Jiambalvo, J. (1991). Incidence and Circumstances of Accounting Errors: Accounting Review, 643-655.

Demir, M., Kısakürek, M., \& Arslan, Ö. (2019). İç Denetim Sisteminin Hileli Finansal Raporlamayı Önlemedeki Rolüne Yönelik Bağımsız Denetçiler Üzerinde Bir Araştırma: Muhasebe ve Finansman Dergisi, 82, 111-134.

Doğan, S., \& Burgazlıŏlu, E. (2015). İç Kontrol Sistemi ve Özel Bir Hastanede Uygulamasi: Kırklareli Üniversitesi Iktisadi ve İdari Bilimler Fakültesi Dergisi, 4(1), 18-33.

Doğan, T. (2018). Hileli Finansal Raporlamanın Önlenmesinde İç Kontrol Sistemi ve İç Denetimin Etkinliği ve Bir Uygulama. Yüksek Lisans Tezi, İstanbul: Okan Üniversitesi, Sosyal Bilimler Enstitüsü.

Dumanoğlu, S. (2005). Hata ve Hile Ayrımı: Hile Denetimi. Marmara Üniversitesi Iktisadi ve İdari Bilimler Fakültesi Dergisi, 20(1). 347-358.

Erdem, Y.C., \& Kaya, C.T. (2015). Hile ile Mücadelede Muhasebe ve Pazarlama Işs birligi: Akademik Sosyal Araştırmalar Dergisi, 3(9), 260-267.

Erdem, Z. (2014). Hile Denetimi ve İç Kontrol İlişkisi. Yüksek Lisans Tezi, İstanbul: İstanbul Ticaret Üniversitesi, Sosyal Bilimler Enstitüsü.

Erdoğan, B. \& Mengi, B.T. (2018). Hata ve Hilelerin Önlenmesine Yönelik Kontroller ve Sağllk Sektörü Üzerine Bir Uygulama: Giresun Üniversitesi İktisadi ve İdari Bilimler Dergisi, 4(2), 85-106.

Erzurum, M. (2014). Özel Hastane İşletmelerinde Muhasebe: İç Kontrol Sistemi ve Swot Analizi. Yüksek Lisans Tezi, İstanbul: Okan Üniversitesi, Sosyal Bilimler Enstitüsü.

Güneş, Ş. (2014). İşletmelerde Hile Riskinin Önlenmesi ve Hastane İşletmelerinde Uygulama. Yüksek Lisans Tezi, İstanbul: Okan Üniversitesi, Sosyal Bilimler Enstitüsü.

Hacıhasanoğlu, T., \& Karaca, N. (2015). Potansiyel Muhasebe Meslek Mensuplarının Hile Algısı Üzerine Bozok Üniversitesi’nde Yapilan Bir Araştirma: Ömer Halisdemir Üniversitesi İktisadi ve İdari Bilimler Fakültesi Dergisi, 8(1), 117 130.

Kayıkçığlu, S. (2017). Şirketlerin İç Denetim Birimlerinde Hile Denetimi ve Bir Uygulama. Yüksek Lisans Tezi, İstanbul: Işık Üniversitesi, Sosyal Bilimler Enstitüsü.

Kertiş, S. (2005). Hastane İşletmelerinde İç Kontrol Sistemi ve Özel Bir X Hastanesinde Uygulanması. Yüksek Lisans Tezi, İstanbul: İstanbul Üniversitesi, Sosyal Bilimler Enstitüsü. 
Kızıltuğ, P. (2015). Hastane İşletmelerinde İç Kontrol Sistemi ve Özel Bir Hastanede İç Kontrol Sistemi Uygulanması. Yüksek Lisans Tezi, İstanbul: Okan Üniversitesi, Sosyal Bilimler Enstitüsü.

Koyutürk, Ö. (2015). İşletmelerde Hile Tespitinin Önemi ve Abc Hastanesinde Bir Uygulama. Yüksek Lisans Tezi, İstanbul: Okan Üniversitesi, Sosyal Bilimler Enstitüsü.

Kurt, P. (2018). Hastane İşletmelerinde Faaliyet Tabanlı Maliyetleme ve Sürece Dayalı Faaliyet Tabanlı Maliyetleme: Kamu Hastanesinde Bir Uygulama. Yüksek Lisans Tezi, Bartın: Bartın Üniversitesi, Sosyal Bilimler Enstitüsü.

Mengi, B. T. (2012). Hile Denetiminde Yetkinliklerin Değerlendirilmesi: Hile Karosu. Mali Çözüm Dergisi, 114, 113-128.

Mengi, B. T. (2013). Sağlık Hizmetlerinde Meydana Gelebilecek Hileleri Önlemeye Yönelik Bir Uygulama Olarak Biyometrik Kimlik Doğrulama Sistemlerinin Kullanımı: Muhasebe ve Finansman Dergisi, (60), 39-50.

Muslimat, A. S., \& Hamid, K. T. (2012). The Role of Internal Audit Unit in Fraud Prevention in Government Owned Hospitals in a Nigerian Setting: IOSR Journal of Business and Management, 2, 39-44.

Özbek, S. B. (2014). Hastane İşletmelerinde Yolsuzluk ve Finansal Tablo Hileleri: İstanbul İl Merkezli Bir Hastane Örneği. Yüksek Lisans Dönem Projesi, Edirne: Trakya Üniversitesi, Sosyal Bilimler Enstitüsü,

Semerci, T. (2010). Hastane İşletmelerinde Bağımsız Denetim ve Bir Uygulama. Yüksek Lisans Tezi, İstanbul: İstanbul Ticaret Üniversitesi, Sosyal Bilimler Enstitüsü,

Tufan, M., (2012). Uluslararası İç Denetim Standartları Çerçevesinde Kamuda İç Denetim: Türkiye'deki İç Denetim Sisteminin Değerlendirilmesi Üzerine Bir Araştırma. Yüksek Lisans Tezi, Çanakkale: Onsekiz Mart Üniversitesi, Sosyal Bilimler Enstitüsü.

Uğurluoğlu, Ö., Çelik, Y., Tengilimoğlu, D., Kılıç, M., Esatoğlu, A. E., \& Şahin, B. (2013). Sağlık Kurumları Yönetimi-II. Eskişehir: Anadolu Üniversitesi Yayın1.

Usul, H., Titiz, İ., \& Ateş, B. A. (2011). İç Kontrol Sisteminin Kurumsal Yönetimin Olusumundaki Etkinliği: Marmara Bölgesi Belediye İsletmelerine Yönelik Bir Uygulama. Muhasebe ve Finansman Dergisi, (49), 48-54.

Yiğittop, V. M. (2008). Özel Hastane İşletmelerinde Muhasebe Uygulamaları ve İç Kontrol Sistemi. Yüksek Lisans Tezi, Ankara: Gazi Üniversitesi, Sosyal Bilimler Enstitüsü.

Yurtsever, G. (2015). İç Denetimin Fonksiyonları ve Katma Değeri: Finans\&Politik ve Ekonomik Yorumlar, 52(602), 89-101.

https://www.ismmmo.org.tr/Egitim/Saglik-Isletmelerinde-Muhasebe-ve-VergiUygulamalari-Seminer-Sunumu--13936 adresinden alındı. 
http://www.gureli.com.tr/pdf/ic-kontrol-hile-ve-hassasiyet-analizi adresinden alındı. 